\title{
A Modified in vivo Flow Variation Technique of Microdialysis for Sampling Uremic Toxins in the Subcutaneous Interstitial Compartment
}

\author{
Leonard Ebah Paul Brenchley Beatrice Coupes Sandip Mitra
}

Manchester Institute of Nephrology and Transplantation (MINT), Central Manchester University Hospitals Trust, Manchester, UK

\section{Key Words}

Uremic toxins $\cdot$ Microdialysis $\cdot$ Interstitium $\cdot$ Chronic kidney disease

\begin{abstract}
Background: Uremic toxins are typically measured in plasma and little is known of their interstitial concentrations. We undertook experiments to validate a microdialysis technique for simultaneous recovery of small and large uremic toxins in the subcutaneous interstitial fluid (ISF). Methods: Microdialysis catheters were inserted into the subcutaneous interstitium of 8 subjects (controls and uremic patients) and perfused using two different solutions at incremental flow rates to determine analyte recovery and ISF concentrations of urea and protein. Results: $10 \%$ dextran-40 perfusate allowed the determination of interstitial concentrations of urea and protein reliably, by virtue of the exponential decay of their concentrations in the microdialysate with incremental flow rates $\left(R^{2}=0.63-0.99\right)$. Interstitial and plasma urea correlated well $(r=0.95)$, as did interstitial urea from distant anatomical sites $(r=0.96)$. Conclusion: Cutaneous microdialysis with dextran-40 allows measurement of small and large molecule concentrations in ISF, creating an opportunity to characterize ISF in uremia.

Copyright $\odot 2011$ S. Karger AG, Basel
\end{abstract}

\section{Background/Aims}

Diminution in renal function results in progressive accumulation of substances known as uremic retention solutes $[1,2]$. Some of these solutes exert deleterious effects on cellular functions and are at least in part responsible for the excess morbidity and mortality seen in patients with chronic kidney disease (CKD) [3-5]. Several authors have catalogued the uremic toxins known to date, with measurements undertaken predominantly in plasma and serum $[1,2]$. There is little data on direct extraplasmatic concentrations of such 'uremic toxins', apart from extrapolations using kinetic modeling. Eloot et al. [6] showed that guanido-compounds behaved differently in plasma and red cells. Metry et al. [7] found that post-dialysis interstitial urea lagged behind plasma urea. These suggest differences in profile and kinetics of known solutes in different fluid compartments. Current renal replacement technologies efficiently remove these toxins from the blood compartment, but rely on passive, unregulated, unquantified transfer from extravascular fluid clinically demonstrated by the 'rebound phenomenon'. There may be a potentially active role with greater clinical significance of extravascular toxin reservoirs such as subcutaneous interstitial fluid (ISF) $[8,9]$. The improved sur-

\section{KARGER}

(C) 2011 S. Karger AG, Basel

Fax +41613061234 E-Mail karger@karger.ch www.karger.com www.karger.com/bpu
Leonard Ebah

Renal Research Laboratories, Manchester Royal Infirmary

Oxford Road, Manchester M13 9WL (UK)

Tel. +441612767915

E-Mail Leonard.ebah@cmft.nhs.uk 
vival with long-hours, slow hemodialysis may relate to a more effective plasma equilibration with interstitial toxins, suggesting that the study of extravascular toxin profile and its redistribution may be important $[10,11]$.

The interstitial compartment is about 4 times the size of the plasma compartment, and is in closer proximity to active cellular structures. It is also dynamic, with a constant exchange between plasma and ISF through pores 6-8 $\AA$ in diameter [12]. ISF proteins and electrolytes have been measured in physiological states in animals and humans, but little is known of the interstitial composition in CKD. The paucity of research is partly due to methodological limitations to ISF sampling.

We wished to develop a microdialysis technique that will sample ISF for simultaneous yield of a wide range of toxins (small and large) in healthy controls and CKD patients.

\section{Methods}

\section{Study Subjects}

Ethical approval was obtained from the National Research Ethics Service (NRES) and University of Manchester Research Ethics Committee. Written consent was obtained from all subjects and studies were performed in accordance with the Helsinki Declaration. Three stage 5 CKD patients on peritoneal dialysis (PD) and 2 before commencing dialysis (pre-dialysis) were recruited at Manchester Royal Infirmary. Three healthy controls were also enrolled in the study. Patients with skin disease and those on warfarin were excluded.

\section{Preparation of Subjects}

Once consented, participants attended a 5-hour experimental session in a temperature-controlled dedicated research environment at the Wellcome Trust Clinical Research Facility, Manchester. Once demographic information was obtained and vital parameters taken, subjects were positioned in a semirecumbent position on a reclining chair, exposing two skin sites (the lower abdomen and the ventral aspect of one forearm). These were cleaned with Chloraprep ${ }^{\circledR}$ and allowed to dry. On each surface, $1 \%$ lignocaine was infiltrated subcutaneously at two points about $30 \mathrm{~mm}$ apart and allowed 1-2 min to take effect. A 21-gauge green needle introducer was then inserted subcutaneously between the two lignocaine-infiltrated points, taking care to stay superficial so as to avoid dermal capillaries. The researcher had undertaken prior formal training from CMA Microdialysis AB, Solna, Sweden.

\section{Microdialysis}

Once the needle was in place, a CMA- $66^{\circledR}$ linear microdialysis catheter (length $30 \mathrm{~mm}$, outer diameter $0.5 \mathrm{~mm}$, molecular weight (MW) cut-off $100 \mathrm{kDa}$; CMA Microdialysis AB) was threaded through the needle and the needle carefully withdrawn, leaving the catheter in the subcutaneous tissue. The catheters were then left in place for a 'cooling off' period of $30 \mathrm{~min}$, to minimize the impact of tissue disturbance during insertion before sampling was commenced. The CMA- 66 catheter connects proximally to a polythene tubing, to which was attached a 2.5-ml CMA-106 syringe containing the perfusion fluid (fig. 1). The syringe was fitted snugly into a dedicated chamber in a CMA- $107^{\circledR}$ micropump, which is designed to perfuse the fluid through the microdialysis catheter at rates of between 0.1 and $5 \mu \mathrm{l} / \mathrm{min}$. The distal end of the microdialysis catheter was connected to polythene tubing which abuts into a pre-weighed 250 - $\mu \mathrm{l}$ microvial into which the microdialysate was collected. Two perfusates (either the manufacturer's T1 perfusion fluid which is similar to Ringer's solution in composition, or $10 \%$ dextran-40, Rheomacrodex ${ }^{\circledR}$; Meda AS, Allerod, Denmark) were compared in terms of volume recovery and analyte capture.

After the 'cooling off' period, both catheters were perfused at the rate of $0.3 \mu \mathrm{l} / \mathrm{min}$ for $1 \mathrm{~h}$, at the end of which the microvials containing the microdialysate were immediately removed and replaced with new ones. This was repeated at $0.5,1.0$ and $5 \mu \mathrm{l} / \mathrm{min}$. The aim of flow variation was to determine the interstitial analyte concentration as described by Hutchinson et al. [13]. The catheter was removed after the last collection (lasting $30 \mathrm{~min}$ ) and a $10-\mathrm{ml}$ EDTA venous blood sample collected. This was later centrifuged for $10 \mathrm{~min}$ at 2,000 rpm and the plasma separated. All samples were stored at $-80^{\circ} \mathrm{C}$ until analysis. All PD patients were drained empty prior to the experiments.

Sample Analysis and Statistics

The samples were analyzed photometrically for urea using a CMA- $600^{\circledR}$ analyzer which uses a urease method on as little as $2-\mu \mathrm{l}$ volumes. The urea detection threshold was $0.5 \mathrm{mmol} / \mathrm{l}$ and the method is linear from 0.5 to $25 \mathrm{mmol} / \mathrm{l}$. Protein concentration was measured at $280 \mathrm{~nm}$ with a Nanodrop ${ }^{\circledR}$ spectrophotometer using the Bradford method with bovine serum albumin (BSA) as the reference. Descriptive statistics, fit data, correlation and t tests were performed using Microsoft Excel ${ }^{\circledR}$.

\section{Results}

\section{Microdialysate Volume Recovery}

Four catheters in 2 participants were perfused with the manufacturer's T1 perfusing fluid (Ringer's). This showed unreliable dialysate recovery due to loss of perfusate into the tissue. Dextran-40 was then used which greatly improved dialysate volume recovery. Figure 2 compares the average dialysate recovery for Ringer's and dextran- 40 at different perfusing rates. At lower perfusion rates $(0.3,0.5$ and $1 \mu \mathrm{l} / \mathrm{min}$ ), there is significant perfusate loss with Ringer's (mean yield $13.14 \pm 18 \mu \mathrm{l}$ compared to $40.1 \pm$ $20 \mu \mathrm{l}$ for dextran-40; $\mathrm{p}=0.0003$ ).

\section{Microdialysate Urea Recovery and Determination of ISF Urea \\ Urea Recovery in T1 (Ringer's)}

Analysis for urea in microdialysates from all 4 catheters perfused with Ringer's solution showed an erratic 
Fig. 1. A microdialysis set-up. The microdialysis catheter with a semipermeable membrane is embedded in tissue, surrounded by ISF. The perfusing fluid is pumped through the catheter at a set rate. Toxins diffuse into the perfusate from the surrounding ISF and a dialysate is collected. The dialysate contains a proportion of the interstitial concentration of the toxin of interest (the relative recovery).

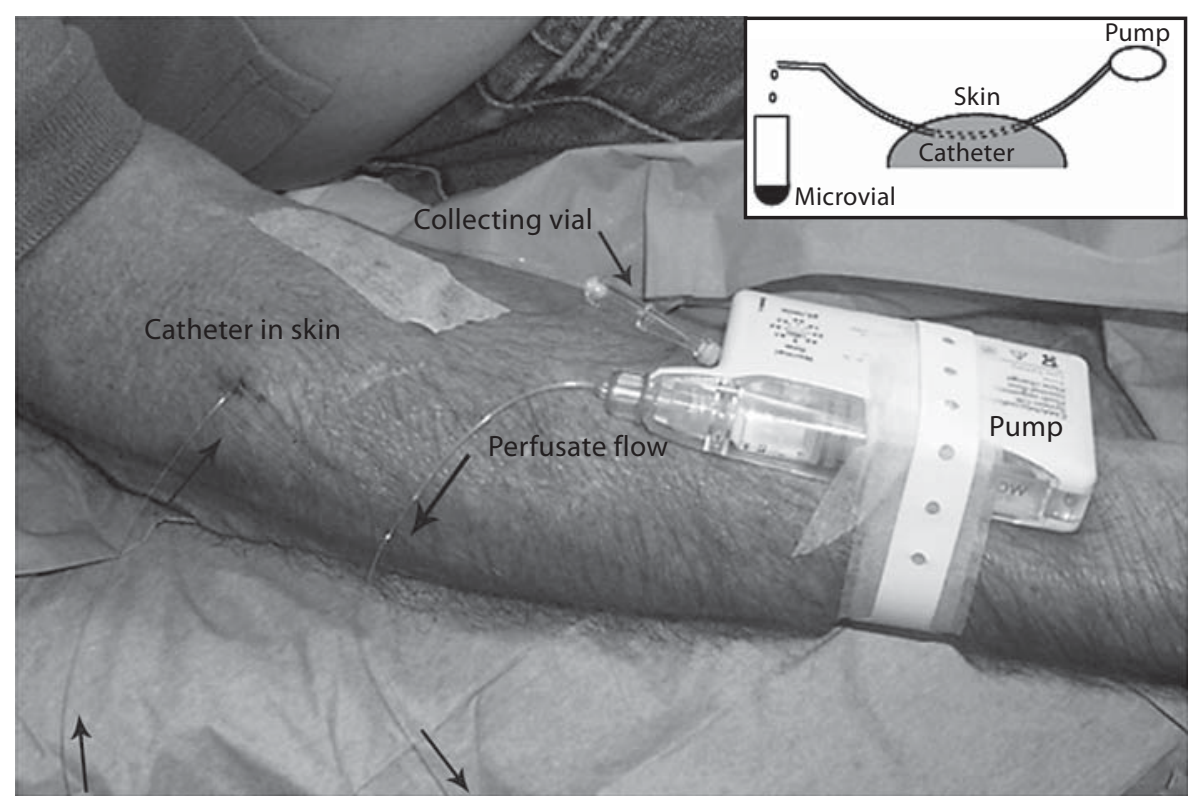

pattern that did not allow determination of ISF urea. In control 1, the exponential curve from dialysate against perfusion rate showed very poor fit between the data points $\left(\mathrm{R}^{2}=0.41\right)$ (fig. 3a), whilst in control 2 , no clear pattern could be found between dialysate urea concentration and perfusion rate (fig. 3b). Ringer's solution therefore seemed to be suboptimal for urea capture.

\section{Urea Recovery and ISF Urea Determination with}

Dextran-40 as the Perfusate

Graphs of dialysate urea concentration against perfusion rate showed an exponential curve, the urea concentration falling exponentially as flow perfusion rate was increased (fig. 4a, 5a). Regression analysis was used to determine the urea concentration at zero flow rates, which is theoretically the urea concentration when the perfusing fluid equilibrates with the fluid surrounding the catheter, i.e. the subcutaneous interstitial urea concentration. Straight-line regression using a natural log scale yielded similar results (fig. 4b, 5b).

Identical methods were used to determine interstitial urea concentration in CKD patients. Interstitial urea correlated remarkably well with plasma urea $(r=0.95)$. Likewise, urea concentrations for abdominal subcutaneous interstitium were quite similar to those in the forearm $(r=0.96)$. Table 1 summarizes interstitial urea concentrations from the two locations (abdominal and forearm skin) and compares them to simultaneous plasma urea concentrations. The median intra- and interassay coef-

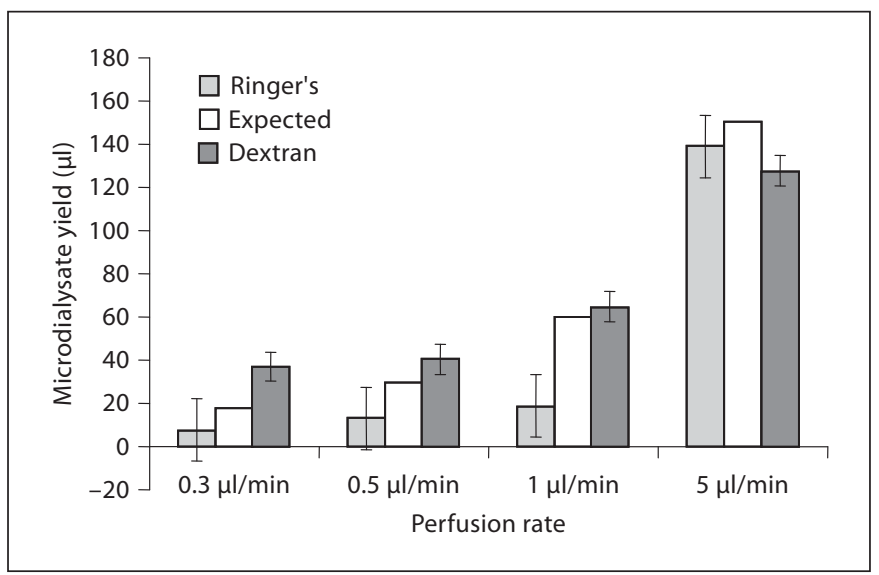

Fig. 2. Dialysate volume yield for the various perfusion rates for Ringer's and dextran-40. Dextran-40 yielded significantly more dialysate at $0.3,0.5$ and $1 \mu \mathrm{l} / \mathrm{min}(\mathrm{p}=0.0003$, $\mathrm{t}$ test $)$.

ficient of variation from 11 paired microdialysate samples analyzed for urea were $2.6 \%$ (mean $3.4 \pm 3.5 \%$, range $0-12.3 \%$ ) and $4.7 \%$ (mean $4.8 \pm 1.3 \%$, range $3.1-6.8 \%$ ) respectively.

\section{Capture of Larger Molecules within the}

Microdialysate: Protein

We measured microdialysates from 4 subjects, 1 control and 3 end-stage renal disease (ESRD), for protein concentrations at the various flow rates, using BSA as the 

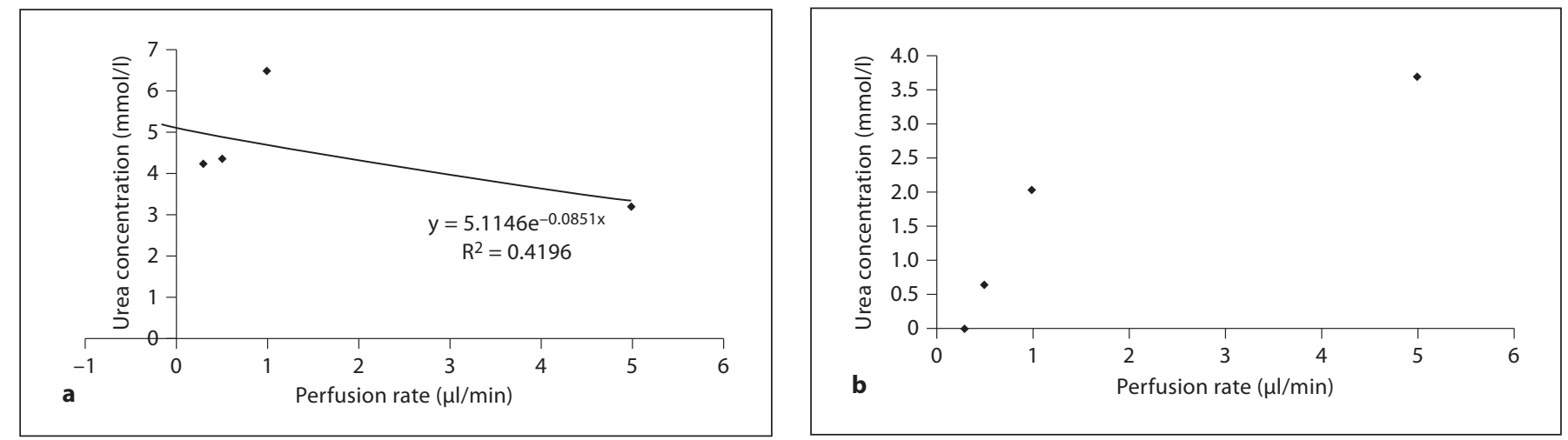

Fig. 3. Graphs of urea concentration against perfusion rate with Ringer's solution as the perfusate. a Control 1: very poor fit from the curve of dialysate urea against perfusion rate $\left(R^{2}=0.41\right)$. b Control 2: very erratic pattern between dialysate urea concentration and flow rate; interstitial concentration could not be determined.
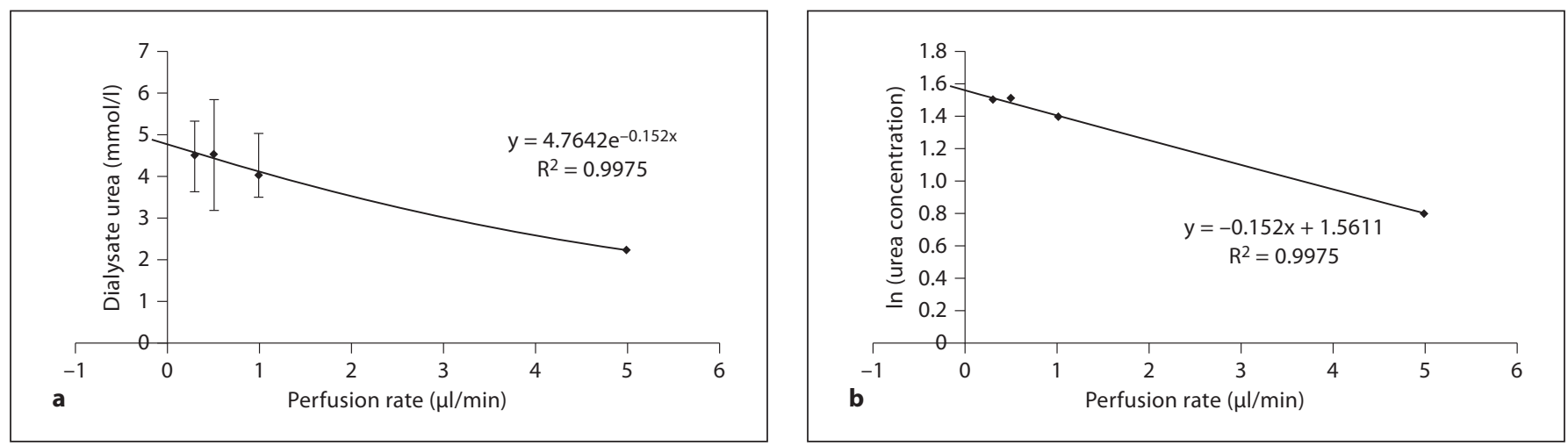

Fig. 4. Determination of ISF urea in a control (control 3) by regression analysis. a Dialysate urea against perfusion rate curve. $\mathbf{b}$ ln (urea) against perfusion rate. There was an excellent fit of all data points around the exponential regression line $\left(\mathrm{R}^{2}=0.99\right)$. Interstitial urea was determined by the $y$-intercept of the curve in $\mathbf{a}$, or the $1 / \ln$ (y-intercept) in b. Both methods yielded the same value for ISF urea ( $4.76 \mathrm{mmol} / \mathrm{l})$; plasma urea was 6.25 $\mathrm{mmol} / \mathrm{l}$.
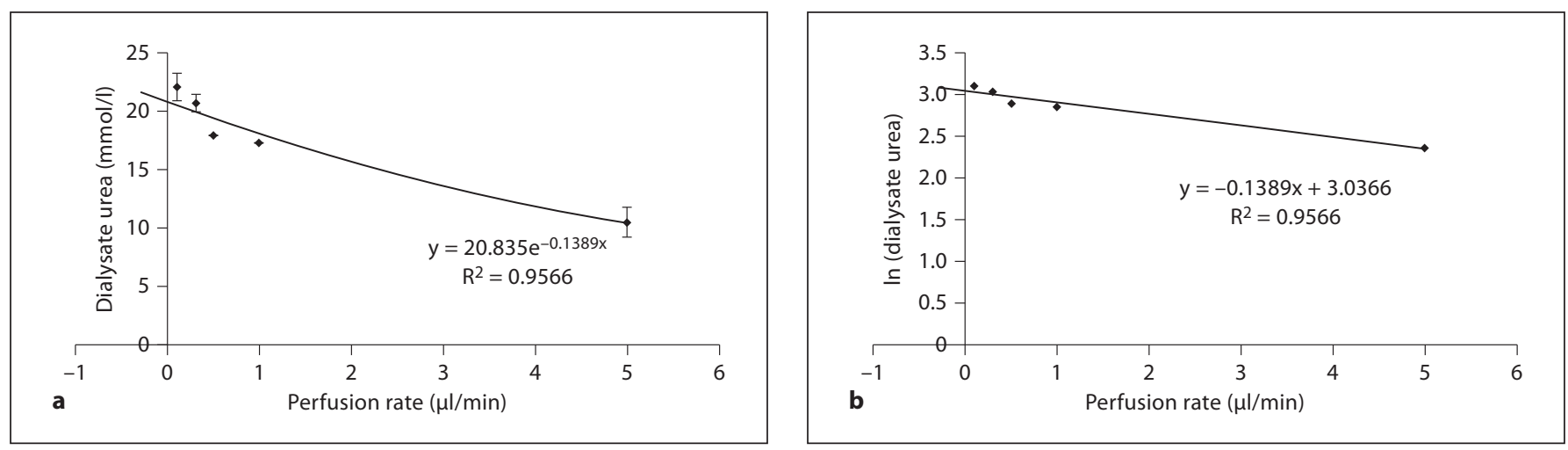

Fig. 5. Determination of ISF urea in a PD patient (patient 4). a Dialysate urea concentration against perfusion rate. $\mathbf{b} \ln$ (dialysate urea concentration) against perfusion rate. ISF urea by both methods was $20.83 \mathrm{mmol} / \mathrm{l}$; plasma urea $17.5 \mathrm{mmol} / \mathrm{l}$. 
Table 1. Summary of urea concentrations ( $\mathrm{mmol} / \mathrm{l}$, mean $\pm \mathrm{SD}$ ) from the abdominal and forearm catheters compared to plasma urea for all 8 subjects

\begin{tabular}{|c|c|c|c|c|c|c|c|c|}
\hline \multirow[b]{2}{*}{ Subject } & \multicolumn{3}{|l|}{ Controls } & \multicolumn{3}{|l|}{ PD patients } & \multicolumn{2}{|c|}{ Pre-dialysis patients } \\
\hline & $1^{\mathrm{a}}$ & $2^{\mathrm{a}}$ & 3 & 4 & 5 & 6 & 7 & 8 \\
\hline Age, years & 22 & 51 & 38 & 72 & 41 & 77 & 70 & 39 \\
\hline Sex & M & $\mathrm{F}$ & $\mathrm{F}$ & $\mathrm{F}$ & M & $\mathrm{F}$ & $\mathrm{M}$ & $\mathrm{F}$ \\
\hline Forearm urea & 5.11 & $\mathrm{PR}$ & 4.76 & 20.84 & 25.79 & 10.68 & 11.01 & 36.42 \\
\hline Curve fit $\left(\mathrm{R}^{2}\right)$ & 0.42 & PR & 0.99 & 0.96 & 0.96 & 0.99 & 0.98 & 0.96 \\
\hline Abdominal urea & PR & PR & 4.01 & 20.53 & 21.8 & 12.26 & 7.63 & $\mathrm{CF}$ \\
\hline Curve fit $\left(\mathrm{R}^{2}\right)$ & $\mathrm{PR}$ & $\mathrm{PR}$ & 0.99 & 0.96 & 0.99 & 0.99 & 0.63 & $\mathrm{CF}$ \\
\hline Mean ISF urea & $\mathrm{PR}$ & $\mathrm{PR}$ & $4.39 \pm 0.53$ & $20.69 \pm 0.22$ & $23.8 \pm 2.8$ & $11.47 \pm 1.1$ & $9.32 \pm 2.4$ & 36.42 \\
\hline Plasma & $5.37 \pm 0.9$ & 7.71 & $5.65 \pm 0.52$ & $17.5 \pm 1.4$ & $26.89 \pm 2.1$ & $12.54 \pm 0.76$ & $12.32 \pm 0.3$ & 28.87 \\
\hline
\end{tabular}

a Ringer's solution was used as the perfusate. In subjects 3-6 in whom dextran-40 was used, there was a good correlation between forearm and abdominal interstitial urea $(r=0.96)$ and between interstitial and plasma urea $(r=0.95)$. This was not the case when Ringer's was used (subjects 1 and 2). The abdominal catheter failed in subject $8 . \mathrm{PR}=$ Poor (analyte) recovery; $\mathrm{CF}=$ catheter failure.

standard. Curves for protein concentration and against flow rate (fig. 6) demonstrated a similar exponential relationship as with urea, showing that the technique can be used to determine interstitial concentrations of toxins over a wide MW range.

\section{Discussion}

Microdialysis has been used extensively for sampling and delivery of molecules in tissues, especially in neurosciences and pharmacology [14]. Studies to employ this technique in renal medicine have focused on the renal interstitium to measure ischemic markers and vasoactive substances [15-17]. Few studies have been undertaken in ESRD using microdialysis. Karamouzis et al. [18] used muscle microdialysis to study markers of oxidative stress in patients with ESRD. More recently, Crowe et al. employed the technique to study markers of oxidative stress in the skeletal muscles of patients on hemodialysis [19]. Metry et al. [7] studied plasma and interstitial urea kinetics in 11 patients during and after hemodialysis and observed that post-dialysis interstitial urea lagged approximately an hour behind plasma levels. Most of the published literature has been on small pore diameter microdialysis catheters, limiting toxin yield. Also, the no-net flux method of calibration employed limited the study to the measurement of one analyte at a time. The standard technique is therefore cumbersome, time-consuming and of limited utility where toxins over a wide range need to be studied simultaneously.

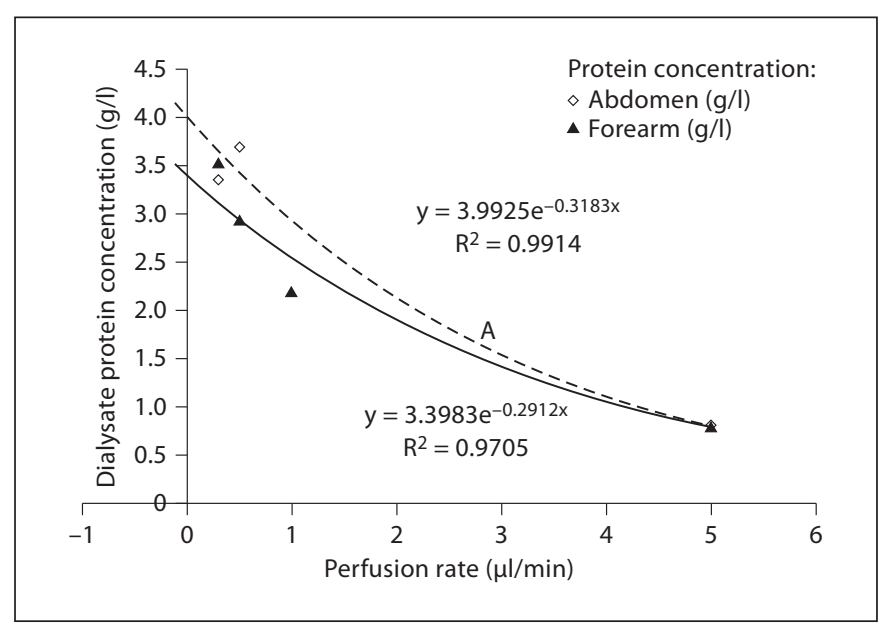

Fig. 6. Graphs of microdialysate protein concentration against perfusion rate in a control (control 3). This shows that with dextran-40, dialysate protein decays exponentially with increasing flow rate $\left(\mathrm{R}^{2}=0.97\right.$ and 0.99$)$. This means larger uremic toxins; the size of albumin could be determined by the flow variation method.

Vanholder et al. [20] have catalogued over 100 known uremic retention solutes of varying physicochemical properties and their potential clinical significance in uremia. We sought to devise a technique that will recover a wide range of toxins and as such enable their simultaneous study during one microdialysis session. The CMA66 catheter has a MW cut-off of $100 \mathrm{kDa}$. This implies that theoretically it should recover toxins of all categories. 
However, it should be noted that recovery depends not only on pore diameter and molecular size, but also on charge, membrane material, perfusate content and tissue characteristics $[14,21,22]$.

\section{Perfusate Volume and Analyte Recovery}

The recovery of a substance into the microdialysate depends on the perfusion or flow rate $\mathrm{F}$, as in the equation $C_{\text {dial }}=C_{t}\left(1-e^{-r A / F}\right)$, where $C_{\text {dial }}$ is the concentration of the substance in the dialysate, $\mathrm{C}_{t}$ is its concentration in the tissue, $r$ is the mass transport coefficient of the membrane, and $\mathrm{A}$ is its surface area $[14,23]$. This is defined by the exponential relationship between flow rate and the analyte concentration in the dialysate. This has been used as a method of calibration in microdialysis and confirmed experimentally $[13,24]$. This method provides the opportunity for in vivo calibration and the possibility of studying more than one analyte simultaneously, relevant in the context of uremia. Graphs of urea concentration against flow rate in our patients and controls showed an exponential decay as flow rate increased $\left(R^{2}=0.63-0.99\right)$. This pattern was also replicated in the laboratories for glucose and even for protein, in effect demonstrating the ability of this system to study several analytes simultaneously.

\section{Optimal Perfusion Rate}

Low perfusion rates allow greater diffusion of compounds into the perfusate and true approximation of their concentrations in ISF, but yield smaller sample volumes. To strike a balance, we chose perfusion rates of 0.3 $\mu \mathrm{l} / \mathrm{min}$ (slow), $0.5 \mu \mathrm{l} / \mathrm{min}$ (slow), $1.0 \mu \mathrm{l} / \mathrm{min}$ (slow), and $5.0 \mu \mathrm{l} / \mathrm{min}$ (fast). The slow perfusion rates increased the accuracy of the system by achieving very high relative recoveries (95-98\% for urea at $0.3 \mu \mathrm{l} / \mathrm{min}$ ) but microliter aliquots posed an analytical challenge. Conversely, the higher perfusion rate enabled larger sample volumes but in turn required very sensitive analytical methods as analyte recovery diminished significantly (mean relative recovery of urea $52.5 \pm 1 \%$ ). The urease method was particularly sensitive enough to detect these levels of urea, but this may not necessarily apply to other toxin assays.

The initial use of the standard perfusate (Ringer's solution) with the CMA-66 catheter resulted in significant perfusate loss as shown in figure 2. Moreover, when the microdialysate was measured for urea concentration, there was a poor relationship between concentration and flow rate. Both these problems were remedied by replacing the perfusate with $10 \%$ dextran- 40 . Some previous authors have used macromolecules to reduce perfusate loss in the tissue [25-27]. They added $40 \mathrm{~g} / 1$ dextran-70 or Ringer-dextran-60 to the standard perfusate to prevent perfusate loss. The choice of $10 \%$ dextran- 40 as the second perfusate was based on its physical characteristics (average MW about one third that of the cut-off of the membrane and colloid osmotic pressure closer to that of ISF), which meant that it would not exert undue osmotic force and thereby dilute the microdialysate. The success of this second perfusate was evidenced by matched dialysate yield volumes to total perfused volumes $(170 \%$ expected yield at $0.3 \mu \mathrm{l} / \mathrm{min}, 109 \%$ at $0.5,94 \%$ at $1 \mu \mathrm{l} / \mathrm{min}$, and $73 \%$ at $5 \mu \mathrm{l} / \mathrm{min}$ ). The ideal perfusion rate with our system therefore is $0.5-1 \mu \mathrm{l} / \mathrm{min}$, which resulted in the best volume recovery compared to the perfused volume (94-109\%). These results indicate that at these perfusion rates, minimal convective fluid transfer or dialysate dilution occurs.

\section{Determination of ISF Concentrations of Urea and Protein}

Regression analysis allowed determination of the theoretical urea concentration at zero flow rates, at which point equilibration is expected to occur between the perfusate and ISF. These methods have been used successfully in brain $[13,23]$ and liver microdialysis [24]. Urea is a small, water-soluble highly diffusible solute. In steady states, one would therefore expect its interstitial concentrations to be very close to those of plasma. This was confirmed in all our participants in whom dextran-40 was used $(\mathrm{r}=0.95, \mathrm{p}=0.99)$. There is lack of data on CKD subjects comparing plasma and interstitial urea levels. Metry et al. [7] found no difference between interstitial and plasma urea during hemodialysis and in non-dialyzed subjects with CKD. This was also the case when urea nitrogen concentration in ISF from healthy animals was compared to plasma or serum concentrations [28, 29].

Interestingly, urea concentrations from abdominal subcutaneous interstitium were similar to those from the forearm $(r=0.96)$, suggesting that the ISF behaves as a single compartment in equilibrium. Animal studies using radiolabeled sodium inserted into subcutaneous tissue cages have previously demonstrated close communication between ISF at two separate anatomical sites [30]. Obtaining protein-free samples was once considered an advantage of microdialysis. However, due to the importance of several proteins and other macromolecules, there have been initiatives to devise a microdialysis system that can recover sufficient amounts of macromolecules to determine their tissue concentrations [26, 27, 31, 32]. Using 
Ringer-dextran-60 and 100-kDa catheters, Hillman et al. [32] recovered up to $1,520 \mu \mathrm{g} / \mathrm{ml}$ total protein in the ISF of injured human brain. Our dialysate protein concentrations were 3-8 times higher at the perfusion rate of 0.3 $\mu \mathrm{l} / \mathrm{min}$. Clough [31] found similar recoveries in human skin with a $300-\mathrm{kDa}$ catheter at a flow rate of $3 \mu \mathrm{l} / \mathrm{min}$ over 1-5 min. The prolonged sample collection time and the slower perfusion rates in our study probably compensated for the relatively smaller pore diameter of our catheters (100 vs. $300 \mathrm{kDa})$. Our data confirms that the exponential relationship between dialysate analyte concentration and flow rate is maintained even for large substances such as proteins. This technique offers a novel opportunity to study the concentration of other interstitial proteins of interest like cytokines, protein-bound toxins like $p$-cresylsulfate, and other large uremic toxins like $\beta_{2}$-microglobulin.

The limitations of this methodology are (a) small aliquots, suitable for analytical methods that can accommodate such volumes, (b) bloodless insertion of a microdialysis catheter that requires formal training and experience, and (c) increased collection time to compensate for low volumes hence requiring steady-state conditions.
Despite these limitations, the technique of microdialysis using a flow variation method in vivo allowed reliable determination of subcutaneous interstitial concentrations of a range of solute sizes simultaneously. This can be utilized to undertake future research to characterize the ISF composition, its redistribution and its significance in uremia.

\section{Acknowledgements}

We would like to thank all the research staff of the Wellcome Trust Clinical Research Facility and Manchester Royal Infirmary who helped us in the realization of this study, particularly Jane Morgan and Kirstine Bowden. Ian Read was particularly helpful with some of the laboratory work and Kate Atkinson with the figures. This work was supported by the NIHR Manchester Biomedical Research Centre, Central Manchester Foundation Trust, The Wellcome Trust Clinical Research Facility and The University of Manchester.

\section{Disclosure Statement}

There are no conflicts of interest to declare.

\section{References}

1 Vanholder R, Van Laecke S, Glorieux G: What is new in uremic toxicity? Pediatr Nephrol 2008;23:1211-1221.

$\checkmark 2$ Vanholder R, Glorieux G, De Smet R, Lameire N: New insights in uremic toxins. Kidney Int 2003;63:S6-S10.

-3 Okuno S, Ishimura E, Kohno K, Fujino-Katoh Y, Maeno Y, Yamakawa T, Inaba M, Nishizawa Y: Serum $\beta_{2}$-microglobulin level is a significant predictor of mortality in maintenance haemodialysis patients. Nephrol Dial Transplant 2009;24:571-577.

-4 Aucella F, Maas R, Vigilante M, Tripepi G, Schwedhelm E, Margaglione M, Gesualdo L, Boeger R, Zoccali C: Methylarginines and mortality in patients with end-stage renal disease: a prospective cohort study. Atherosclerosis 2009;207:541-545.

5 Cheung AK, Rocco MV, Yan G, Leypoldt JK, Levin NW, Greene T, Agodoa L, Bailey J, Beck GJ, Clark W, Levey AS, Ornt DB, Schulman G, Schwab S, Teehan B, Eknoyan G, for HSG: Serum $\beta_{2}$-microglobulin levels predict mortality in dialysis patients: results of the HEMO study. J Am Soc Nephrol 2006;17: 546-555.
6 Eloot S, Torremans A, De Smet R, Marescau B, De Deyn PP, Verdonck P, Vanholder R: Complex compartmental behavior of small water-soluble uremic retention solutes: evaluation by direct measurements in plasma and erythrocytes. Am J Kidney Dis 2007;50: 279-288.

7 Metry GS, Attman P-O, Lonnroth P, Beshara SN, Aurell M: Urea kinetics during hemodialysis measured by microdialysis - a novel technique. Kidney Int 1993;44:622-629.

$\checkmark 8$ Paniagua R, Amato D, Vonesh E, CorreaRotter R, Ramos A, Moran J, Mujais S: Effects of increased peritoneal clearances on mortality rates in peritoneal dialysis: ADEMEX, a prospective, randomized, controlled trial. J Am Soc Nephrol 2002;13: 1307-1320.

-9 Eknoyan G, Beck GJ, Cheung AK, Daugirdas JT, Greene T, Kusek JW, Allon M, Bailey J, Delmez JA, Depner TA, Dwyer JT, Levey AS, Levin NW, Milford E, Ornt DB, Rocco MV, Schulman G, Schwab SJ, Teehan BP, Toto R, the HEMO Study Group: Effect of dialysis dose and membrane flux in maintenance hemodialysis. NEngl J Med 2002;347:2010-2019.

-10 Covic A, Goldsmith DJA, Venning MC, Ackrill P: Long-hours home haemodialysis - the best renal replacement therapy method? QJM 1999;92:251-260.
11 Charra B, Chazot C, Jean G, Laurent G: Long, slow dialysis. Mineral Electrolyte Metab 1999;25:391-396.

12 Guyton AC, Hall JE: Textbook of Medical Physiology, ed 11. Philadelphia, Elsevier Saunders, 2006.

13 Hutchinson PJ, O'Connell MT, Al-Rawi PG, Maskell LB, Kett-White R, Gupta AK, Richards HK, Hutchinson DB, Kirkpatrick PJ, Pickard JD: Clinical cerebral microdialysis: a methodological study. J Neurosurg 2000; 93:37-43.

14 Plock N, Kloft C: Microdialysis - theoretical background and recent implementation in applied life sciences. Eur J Pharm Sci 2005; 25:1-24.

$\checkmark 15$ Tokuyama H, Hayashi K, Matsuda K, Kubota E, Honda M, Okubo K, Takamatsu I, Ozawa Y, Saruta T: Role of nitric oxide and prostaglandin $E_{2} \alpha$ in acute renal hypoperfusion. Nephrology 2003;8:65-71.

16 Baranowski RL, Westenfelder C: Estimation of renal interstitial adenosine and purine metabolites by microdialysis. Am J Physiol Renal Physiol 1994;267:F174-F182.

17 Nishiyama A, Majid DSA, Walker M III, Miyatake A, Navar LG: Renal interstitial ATP responses to changes in arterial pressure during alterations in tubuloglomerular feedback activity. Hypertension 2001;37:753-759. 
-18 Karamouzis I, Grekas D, Karamouzis M: Enhanced oxidative stress with a gradient between plasma and muscle interstitial fluid in patients with end-stage renal failure on hemodialysis. Hormones (Athens) 2008;7:6269.

-19 Crowe AV, McArdle A, McArdle F, Pattwell DM, Bell GM, Kemp GJ, Bone JM, Griffiths RD, Jackson MJ: Markers of oxidative stress in the skeletal muscle of patients on haemodialysis. Nephrol Dial Transplant 2007;22: 1177-1183.

20 Vanholder R, Meert N, Schepers E: Uremic toxins: do we know enough to explain uremia? Blood Purif 2008;26:77-81.

21 Stenken JA: Methods and issues in microdialysis calibration. Analyt Chim Acta 1999; 379:337-358.

-22 Khramov AN, Stenken JA: Enhanced microdialysis extraction efficiency of ibuprofen in vitro by facilitated transport with $\beta$-cyclodextrin. Analyt Chem 1999;71:1257-1264.
23 Jacobson I, Sandberg M, Hamberger A: Mass transfer in brain dialysis devices - a new method for the estimation of extracellular amino acids concentration. J Neurosci Methods 2010;15:263-268.

24 Scott DO, Lunte CE: In vivo microdialysis sampling in the bile, blood, and liver of rats to study the disposition of phenol. Pharm Res 1993;10:335-342.

25 Hamrin K, Rosdahl H, Ungerstedt U, Henriksson J: Microdialysis in human skeletal muscle: effects of adding a colloid to the perfusate. J Appl Physiol 2002;92:385-393.

26 Dostálová I, Pacák K, Nedvídková J: Application of in vivo microdialysis to measure leptin concentrations in adipose tissue. Int J Biol Macromol 2003;32:205-208.

27 Hillman J, Aneman O, Anderson C, Slorgen F, Saberg C, Pekka M: A microdialysis technique for routine measurement of macromolecules in the injured human brain. Neurosurgery 2005;56:1264-1270.
28 Kayashima S, Arai T, Kikuchi M, Nagata N, Ito N, Kuriyama T, Kimura J: Suction effusion fluid from skin and constituent analysis: new candidate for interstitial fluid. Am J Physiol Heart Circ Physiol 1992;263:H1623H1627.

29 Schmook FP, Nefzger M, Laber G, Georgopoulos A, Czok R, Schütze E: Composition of fluids from diffusion chambers implanted in the soft tissue and kidneys of rabbits. Infection 1980;8:156-161.

-30 Calnan JS, Pflug JJ, Chisholm GD, Taylor LM: Pathophysiology of tissue fluid. Proc R Soc Med 1972;65:715-719.

31 Clough G: Microdialysis of large molecules. AAPS J 2005;7:E686-E692.

>32 Hillman J, Milos P, Yu ZQ, Sjögren F, Anderson C, Mellergård P: Intracerebral microdialysis in neurosurgical intensive care patients utilising catheters with different molecular cut-off (20 and $100 \mathrm{kDa})$. Acta Neurochir 2006;148:319-324. 